TI 2014-008/VI

Tinbergen Institute Discussion Paper

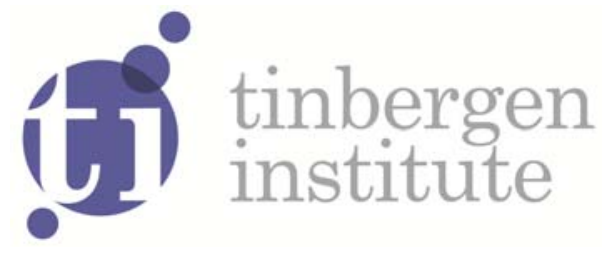

\title{
Prospects for an EMU between Federalism and Nationalism
}

Frank A.G. den Butter

Mathieu L.L. Segers²

1 Faculty of Economics and Business Administration, VU University Amsterdam, and Tinbergen Institute, The Netherlands;

2 Utrecht University, Utrecht, The Netherlands. 
Tinbergen Institute is the graduate school and research institute in economics of Erasmus University Rotterdam, the University of Amsterdam and VU University Amsterdam.

More TI discussion papers can be downloaded at http://www.tinbergen.nl

Tinbergen Institute has two locations:

Tinbergen Institute Amsterdam

Gustav Mahlerplein 117

1082 MS Amsterdam

The Netherlands

Tel.: +31(0)205251600

Tinbergen Institute Rotterdam

Burg. Oudlaan 50

3062 PA Rotterdam

The Netherlands

Tel.: +31(0)10 4088900

Fax: $+31(0) 104089031$

Duisenberg school of finance is a collaboration of the Dutch financial sector and universities, with the ambition to support innovative research and offer top quality academic education in core areas of finance.

DSF research papers can be downloaded at: http://www.dsf.nl/

Duisenberg school of finance

Gustav Mahlerplein 117

1082 MS Amsterdam

The Netherlands

Tel.: +31(0)20 5258579 


\title{
Prospects for an EMU between federalism and nationalism
}

Frank A.G. den Butter ${ }^{a}$ and Mathieu L.L. Segers ${ }^{b}$

January 2014

\begin{abstract}
Which ways and means are available for the macroeconomic and fiscal coordination and/or integration within the EMU-framework? Which are the pros and cons of these scenarios? This paper combines economic theory, empirical analysis and insights regarding EMU's institutional history in order to come to a compromise proposal for an EMU between nationalism and federalism. We take the present status quo acts as a starting point. We describe the tension between the arguments in economic theory on policy coordination and the way contagion can be avoided. In addition we assess the practical political implementation of these arguments. We sketch concrete options for a 'deepening of economic coordination' in the EMU, as announced by Van Rompuy in his 2013 London speech, without moving to a full-fledged federalist EPU.
\end{abstract}

Keywords: history of EMU, 'Krönungstheorie', optimal currency area, policy coordination, contagion, EPU, social preferences, EMU's future.

JEL codes: E61, F55, G15, H77, N14

\footnotetext{
a Professor of Economics, VU University Amsterdam and Tinbergen Institute, email: f.a.g.den.butter@vu.nl

${ }^{\mathrm{b}}$ Assistant Professor of European Integration, Utrecht University, email: M.L.L.Segers@uu.nl
} 


\section{Prospects for an EMU between federalism and nationalism}

\section{I ntroduction}

The institutional challenge of the EU has been the creation of a balance between the intergovernmental and supranational elements. This in order to to enhance and maintain the integration of member states which are diverse in their historical traditions and social preferences. An overarching aim of this exercise is to reconcile national identities and preferences with welfare gains inherent in cooperation and integration within the framework of the internal market. In general, this implies that the EU-integration neither represents the formation of a federalist state which mimics the US, nor can refrain from deepening of (market) integration in those fields where this is welfare enhancing.

From an historical perspective, the balancing between intergovernmental and supranational governance always has been at the heart of the policy discussions and negotiations between the member states of European integration (Cini, 2007, p.2; Anderson, 2009, pp. 3-47). The current complicated governance structures, on which the present day EU has been built, are a result of this balancing act. Since the coming into force of the Lisbon Treaty, these structures encapsulate the so-called 'Community Method' ${ }^{1}$, as well as the European summits held by the heads of state in the form of the European Council (Baldwin and Wyplosz, 2012, pp. 54-55).

The founding of the European Economic and Monetary Union (EMU), the introduction of the euro as a single currency and the delegation of monetary policy to the European Central Bank (ECB), further complicate the maintenance of EU's balanced governance structure. Stronger even, at present, monetary

\footnotetext{
${ }^{1}$ Communitarian integration or the 'Community method' is the expression used for the institutional operating mode which proceeds from an 'integration logic' that strives for the strengthening of the following features: (1) European Commission(s)'s monopoly of the right of initiative; (2) general use of qualified majority voting in the Council of Ministers; (3) an active role for the European Parliament (in co-legislating); and (4) uniformity in the interpretation of Community law ensured by the Court of J ustice.
} 
integration puts extra pressure on the existing modes of governance in the EU. These new pressures partly stem from the fact that, although the list of alleged welfare effects of a monetary union may be long (Beetsma and Giuliodori, 2010), the weighing of the pros and cons that underpins this inventorying gives rise to much and heated discussion, both from a political and an economic point of view.

A monetary union requires sophisticated economic policy coordination between its member states. According to the theory of optimal currency areas (OCA), economic convergence between the member states may enhance the feasibility of such coordination (see e.g. Baldwin and Wyplosz, 2012, chapter 15). If this is the case, a common monetary policy is set up to deal with symmetric shocks, whereas asymmetric - country specific - shocks are absorbed through national fiscal policies (restricted by negotiated conditions on the size of public deficits and debts) and labour market policy (see e.g. Bayoumi and Eichengreen, 1992, Verhoef, 2003). Originally, the process of EMU-building, as set in motion by the Treaty of Maastricht (1992), followed this logic. The no bailout clause that was included in the Treaty of Maastricht was aimed at preventing countries from running into large deficits when hit by asymmetric shocks. It should guarantee a certain degree of fiscal discipline in the EMU. The rationale behind it was that large deficits and the resulting public debts could endanger the value of the euro. However, the rules that formed the so-called excessive deficit procedure in the Treaty of Maastricht (section 104C) were not strictly quantitative, not binding and strongly intergovernmental (Consolidated version of the Treaty on European Union, 2002, art. 104; Van Riel and Metten, 2000, p. 59).

The recent banking and sovereign debt crises exposed the large policy gap between the theory-driven EMU-politics of the past decades on the one hand (compare Jabko, 1999, pp. 475-495), and their economic and political feasibility in day to day monetary management of the Euro-zone on the other. As from the start of the financial crisis in Europe, the no bailout clause of the EMU treaty lost credibility due to the danger of contagion. The latter was transmitted from large banks that supposedly were too interdependent to fail. We now know the outcome: governments ended up rescuing these banks through bailouts. 
The unprecedented unfolding of events during the crisis fit within a broader process of gradual credibility loss regarding budgetary discipline in the Eurozone. This process was already under way during the years that preceded the crisis.

The peloton start of the euro in 1999 and the compliance crisis concerning the Stability and Growth Pact (SGP) in 2003 (with France and Germany forcing the ECOFIN Council to call upon the 'special circumstances clause', so as to allow them to run higher deficits than the $3 \%$ agreed to in the pact), proved that the rules of the SGP with respect to deficits (3\% GDP) and debts (60\% GDP) were considerably less strict than often perceived - particularly in the northern member states of the Euro-zone such misperceptions had had the status of uncontested common knowledge. In fact, the SGP was not more than a gentlemen's agreement between the Finance Ministers of the Euro-zone, who professed their intention not to free ride by adopting irresponsible budgetary policies (Segers and Van Esch, 2007, pp. 1104-6). ${ }^{2}$ Shortly after the SGP compliance crisis of 2003, the Prodi Commission decided to relax the SGP-rules permanently, after its president had gone on record to call the SGP 'stupid'. That was the end of the gentlemen's agreement.

A key consequence of this episode in EMU history has been that the institutional construction of EMU and Euro got decoupled from the theoretical assumptions that were supposed to build its foundation. After all, according to those assumptions, it ought to be labour market policy and/or structural reform of the labour market that should enable member states to cope with country specific asymmetric shocks, redress excessively high deficits and accumulating debts, and fight deteriorations in the competitive position resulting from that. However,

\footnotetext{
${ }^{2}$ The Resolution on the SGP, adopted by the European Council of Amsterdam (17 J une 1997) refers to the 'clear treaty obligation' to avoid excessive general government deficits, it also underlines however that 'Member States remain responsible for their national budgetary policies, subject to the provisions of the Treaty; they will take the necessary measures in order to meet their responsibilities in accordance with those provisions'. Critically, the resolution states that 'the Council ... is invited always state in writing the reasons which justify a decision not to act, if at any stage of the excessive deficit or surveillance of budgetary positions procedures the Council did not act on a Commission recommendation'. Furthermore, the SGP consists of two additional Council Regulations (EC 1466/97 and 1467/97 of 7 July 1997).
} 
in the real world of the EMU and the Euro these shocks were accommodated by something quite different: lax fiscal policy. This came at a cost: high deficits and mounting debts, especially in the southern member states.

These 'accommodating' fiscal policies in euro member states were stimulated further by the relatively low interest rates that had to be paid for debts denominated in Euros. In other words, there existed no serious penalty for running a large government debt, quite the contrary. Eventually, this contributed to growing imbalances between high debtor and creditor Euro-members, with the latter financing the debts of the former. This not only enhanced the danger of contagion, it made bailouts almost inevitable when the financial markets finally realized that the whole Euro-project might be in danger because of unsustainable sovereign debts.

The series of bailouts that followed, caused much political turmoil, both in the member states ending up financing this crisis management (as concerns about money transfers to member states with lax fiscal policies soared), and in the member states that had to be bailed out (as these countries were confronted with the harsh 'conditionality' that came with the rescue financing and felt robed of essential features of their sovereignty). All in all, the Euro-zone and EMU were overwhelmed by events. The institutions of the monetary union proved to be inadequate and unfit to measure up to the challenge. Europe got entangled in an ad hoc crisis management of trial and error, rooted in political power struggles, which were played out during a continuous series of European summits and were dominated by Germany and its northern European allies. Disordering policy discussions set the tone.

From a more general perspective, the crisis has unveiled deep splits and fundamental disagreement among EU's member states and peoples regarding the viability of the EMU and the Euro. Illustratively, federalist Europhiles keep arguing that the only real way out of the crisis is a true federal Europe with a full-fledged European Political Union (EPU) (Habermas, 2012; The Spinelli Group/Bertelsmann Stiftung, 2013), whereas more patriotic Euro-sceptics suggest to abort the EMU and Euro experiment altogether, supporting a multi- 
speed monetary union and/or a return to a Europe of nation states with their own currency and political autonomy (cf. Heisbourg, 2013).

Although these two scenarios still frame much of the public debate about the Euro and its future, they appear rather off the mark when addressing the facts of the present state of affairs. A full-fledged EPU is not in accordance with preferences of the majority of the European voters, and hence not quite feasible from a democratic-political point of view. But a return to a Europe of nation states represents a route irrationally risky and costly from an economic point of view, as it would threaten significant portions of the welfare that have been dependent on the parallel pushes for further market integration and common currency.

Therefore, this paper tries to intermediate between these two extremes. We advocate continuing the road of balance and compromise. However, following that road requires a clear vision on how economic and monetary governance between federalism and nationalism can be institutionalized, taking the present situation as a starting point. What is the state of affairs? Which policy options remain feasible?

The outline of this article is as follows. In the next section we discuss some recent statements by the President of the European Council, Herman van Rompuy, which illustrate the key challenges of the present situation in EMU and the Euro-zone. In section three we then concisely delve into the history of EMU, the expectations originally placed in it and what came from them. Subsequently, in section four, we deal with the economic prescriptions for policy coordination in a monetary union and the difficulties of interpreting and executing these prescriptions in section four. In section five we explain how the threat of contagion, which resulted from systemic flaws within the financial sector and were transmitted to the Euro-zone - eventually forcing the Euro-zone to bailout member-states with unsustainable debts. We discuss some concrete prospects for a middle road between the extremes of a federalist Europe and a Europe of autarkic nation states in the sixth and concluding section. Arguments from game theory suggest a new design of rules for fiscal policy, in which financial markets 
have a stabilizing rather than a destabilizing (key) role in the economic and monetary governance, and which may bring about greater fiscal discipline.

\section{Van Rompuy's refutation of a federal Europe}

Speaking in the City of London on 28 February 2013, the President of the European Council, Herman van Rompuy, gave his reaction to the infamous in-orout EU-speech of UK's prime minister David Cameron, earlier that year. Everybody realised that Van Rompuy's trip to the other bank of the canal was a precarious endeavour. Not many noticed, however, that the President of the European Council did not limit himself to answering the cry from the United Kingdom. He also used the occasion to launch his vision on the future. Van Rompuy seized the opportunity to go beyond the direct concerns of the British and share some reflections on the future of European integration, and its monetary project in particular. And he was rather clear regarding the way ahead: "we are not witnessing the birth pangs of a federal "Euroland". Changing the EU treaties is therefore not the priority'.

According to the President, EU's 'top priority' ought to be something different: 'deepening economic coordination'. To hammer the message home, Van Rompuy got quite explicit about what this meant. He strongly emphasised the need for 'evolution not revolution' in the matter of EMU-development (Van Rompuy, 2013). In striking contrast to his pose of pragmatic modesty however, revolution was precisely what Van Rompuy preached. What the President seems to have been trying to do on that February-day in London in 2013 was to burry EPU, the political union. From a historical perspective, that is not what we call a modest ambition.

In many respects, EPU represents little less than the only imaginable finalité politique of European integration. As such, EPU has been an inspirational visionary thing since EU's days of inception. EPU's conceptual elegance and the analogy with successful historical examples of federation building characterized by peace and prosperity (such as the USA and the FRG), have made EPU the superior grand design in European integration's realm of hope. Today EPU forms the mythical project that, according to many, would be the panacea to cure the Euro-zone and the EMU of their deep flaws. 
During the sovereign debt crisis with its maddening complexities, the EPU-lobby has been gaining momentum precisely because of its conceptual simplicity (as has the equally straightforward lobby that wants to give up the European project altogether on the other extreme of the continuum of solutions). But there is another reason for the growing support for EPU: there sit some very powerful players on the pro-EPU side in post-Maastricht Europe. Three groups in that camp stand out.

Firstly, the high representatives of the German financial elite, in particular the representatives of the Bundesbank, traditionally are strong supporters of EPU (cf. Deutsche Bundesbank 1992). Overall, the German financial elite still remains loyal to the forceful logic of the classic ('ordoliberal') Krönungstheorie. According to this theory EMU, ultimately, is untenable without EPU. Therefore EMU should have completed EPU, instead of the regrettable other way around that was decided upon by Europe's politicians under the pressure of the events of high politics in 1989-91 and written down in the Treaty of Maastricht, while the German financial elite and the rationale of the Krönungstheorie were sidelined (Segers and Van Esch, 2007, pp. 1096-98).

Secondly, the present EPU-lobby may reckon with a fanatic push coming from a wide range of European politicians and prominent convinced 'Europeans', like the former Belgian premier Guy Verhofstad.

Thirdly, EPU's revival is carried by continuous subtle pro-EPU interventions engineered by technocrats in EC and ECB circles. The so-called Outright Monetary Transactions (OMT) programme, which the ECB started in August 2012, may be seen as an example, as it silently transfers policy responsibilities to a supranational EU-level. However, in the matter of OMT this represents an act of pragmatic functional spillover, i.e. a transfer of competences under the pressure of unforeseen circumstances with institutional legitimatization only following this a fait accompli, which politicizes the ECB (this made Germany's Central Bank president Jens Weidmann vote against OMT - moreover he argued that it might erode 'the willingness of Euro zone member-states to implement reforms'). 
Fourthly, and probably most importantly, reluctant but consistent support for EPU has been coming from some of Berlin's top politicians, Wolfgang Schäuble and Angela Merkel (Hewitt, 2013, p. 173; Schäuble in Bild am Sontag, 12 December 2010). Moreover, France and Germany toy again with the opportunity of a crucial trade-off, which is on the cards since the earliest stages of consultations in the wake of the Maastricht negotiations in 1989. Back then Kohl's Germany supported the French-inspired EMU-project, but never managed to capitalize on what Germany's financial experts demanded in exchange for this support, namely strict and enforceable budgetary discipline. Now Merkel is on a quest to set this record straight. Merkel's Germany guarantees the survival of the euro in exchange for future treaty change necessary to secure budgetary discipline in the Euro-zone by supranational means and to strengthening democratic legitimatization. The latter represents a year-old German goal, often even formulated in the straightforward terms of EPU. This 'europeanisation' of budgetary policies is something the German financial elite desired since the signing of Maastricht but failed to achieve - most notably in the 'Maastrichtrevision' treaty of Amsterdam in 1997. In the run-up to 'Amsterdam' the then German Minister of Finance firmly pushed his Stabilitätspakt für Europa (the infamous Waigel-plan named after him), including an independent supervisioninstitution called Stabilitätsrat, the establishment of which would require treaty change (Bundesministerium der Finanzen, November 1995).

What Van Rompuy did in London in 2013, was quitting the powerful EPU-lobby quite bluntly. This implicitly meant that he labelled the pro-EPU movement rooted in the legacy of the European Saints a rather hopeless ancien regime. Van Rompuy, representing the Europe of the member states apparently does not buy the newest old logic of spill over. He openly challenges the argument that EPU builds an indispensible element for a resilient future EMU and euro, which harks back to the days of the European Commission presidency of J acques Delors (cf. Attali, 1995, III, p. 505). Of course, Van Rompuy's positioning in this matter fits his intergovernmental jacket as the president of the European Council. But there is more to it. Van Rompuy's breach with the EMU-legacy of Delors defines a new and vast field for research. 
Tomasso Padoa-Schioppa, one of the most prominent EMU-architects of the Delors era, when evaluating EMU as early as 1994, concluded that monetary integration through 'voluntary cooperation', was bound to fail. He explained that a 'voluntary' kind of integration eventually would make the institutional structure of EMU an empty shell - 'it makes for discussion, but not decision' (PadoaSchioppa, 2000, pp. 204-5). Yet, this is exactly what Van Rompuy now has proposed in order to draw 'all the consequences from the interdependence that comes with sharing a currency': 'deepening economic coordination', in the form of voluntary cooperation - as opposed to supranational integration (Van Rompuy, 2013). According to his reading, the key question is how to manage macroeconomic and fiscal policy from within the existing institutional set-up of EMU. In other words, precisely from within what Padoa-Schioppa labelled an empty shell. Given the recent developments within the EMU and Euro-zone, this paradoxical task, indeed may be the overarching EMU-issue for the years to come.

The extent to which the EU will prove fit to measure up to this task, will define the options still open to the EMU, the EU, and ultimately, to European integration as such. This urges scholars to delve into the twilight zone of the policy grey within the empty shell, the interface between the supranational and the intergovernmental. What 'deepening economic coordination' entails as yet remains largely unclear, both from the political and from the economic perspective.

How did EMU get entangled in this situation? Why was it that the member-states refrained from more policy coordination under the ' $E$ ' of EMU during the earlier stages of monetary integration? The answer to this question is to be found in a significant gap between the image and the reality of EMU's architecture, especially in the North Western part of the Euro-zone.

\section{EMU's unforeseen evolution}

Traditionally, the FRG was highly sceptic about any integration move towards full monetary union. For decades, the West-German financial elite - following the above mentioned Krönungstheorie - was consistently opposed to any EMU that would precede the full economic convergence of the economies of such a future 
union. In brute reality this meant that they saw adaptation to the competitive West German export model as a conditio sine qua non for EMU. EMU had to be the final and ultimate step of a process of economic convergence. ${ }^{3}$

According to the existing historiography, it were the turbulent developments in the period 1989-91 - the fall of the Berlin Wall and German reunification - that enabled a pro-EMU coalition, mainly consisting of France, Italy and the EC, to defeat the untouchables of the West-German financial elite. Although this analysis appears to be correct in many ways as more primary sources become available, it also obfuscates the fact that the German EMU-sceptics already had lost critical ground in the struggle for a European regime for monetary stability before 1989. This is especially true for the period after the coming about of the Single European Act (SEA). Most crucially, during that period a series of decisions was taken, leading up to the complete liberation of the movement of capital on Europe's internal market. This fundamentally changed the institutional context and decisively weakened Bonn's and Frankfurt's EMU-resistance. To understand why, we have to go back to the early 1980s.

During the ECOFIN council of 15 March 1982, the Dutch minister of Finance, the Christian Democrat Fons van der Stee, reacted to a new endless list of the EC with numerous kinds of variants of future EMU. The Dutchman pleaded for a change of the agenda. Was it not high time to focus on something different instead of lofty schemes for EMU? Van der Stee suggested concentrating efforts on the liberalization of capital, an almost forgotten goal in the Treaty of Rome.

\footnotetext{
${ }^{3}$ Although the largely politically motivated pro-EMU initiatives of the SPD-chancellors Willy Brandt and Helmut Schmidt, as from the early 1970s, forced the financial elite of Frankfurt and Bonn somewhat in the defensive, overall the Bundesbank and its allies remained in charge of the German position on EMU. Stronger even, the creation of the European Monetary System (EMS) during the late 1970s (replacing the snake) made the Bundesbank more powerful than ever before in Western Europe. By then it seemed quite certain that German financial elite would manage to continue to ward off full-fledged EMU. This was heavily underlined by the infamous Emminger letter, which the president of the Bundesbank (Otmar Emminger) sent off to chancellor Schmidt during the crucial phase of the EMS-negotiations in December 1978. This letter forced the chancellor to secure that the Bundesbank could refrain from the support interventions in Europe's money markets as prescribed by the EMS in the case of conflict between such an action and the monetary policy of the Bundesbank - i.e. the primary goal of price stability (Ludlow, 1982, p. 167).
} 
During the months that followed, Dutch monetary diplomacy managed to get the issue on the agenda of the Monetary Committee (Delors, 2004, p. 385; Bakker, 1996, pp. 147-55). And there was a reason. The liberalization of capital movement could be linked to EMU.

The connection between EMU and the liberalization of capital movements was forged using the OCA-theory. After all, according to the OCA-theory free movement of capital builds a hard precondition for any monetary union (cf. Mundell, 1961, pp. 657-65; Mourlon-Druol, 2012, pp. 15-16). In other words: talking about EMU required fixing free movement of capital first. The FRG and the UK backed this approach. Both countries already had liberalized the movement of capital completely and they reckoned with the disciplining the financial markets would force upon the less stable economies of the European Community. By then, it looked like the Dutch had found the 'big financial stick' to force the more southern EC-members in the German line of discipline before EMU talks could become ambitious again (Oort, 1974, pp. 45-52).

The proponents of EMU gradually realized that they had to take on board the free movement of capital on Europe's internal market, if they wanted to make progress on the EMU-front. The Northern Europeans had to be appeased in the issue of capital liberalization. Eventually this was accomplished in Delors' White Book of J une 1985 that laid the foundations upon which the SEA could be launched, negotiated and signed. A crucial element in the package concerned EMU. Ongoing deliberations in the Monetary Committee had brought about consensus over the principle that the strengthening of the EMS (i.e. development in the direction of EMU) and free movement of capital were two sides of the same coin (J abko, 1999, pp. 478-80).

From a pro-EMU stance, the break trough was that fresh institution building on the basis of the SEA could start now. And in Paris, Mitterrand, the man who would become EMU most fervent fan, was well aware of this (Attali, 1993, I, pp. 1343-45).

During the second half of the 1980s Delors was endowed with the task to create the institutions necessary to seize the opportunity to launch full-fledged EMU 
when les circonstances would turn to the better and create some sort of EMUmomentum. During the ECOFIN Council of 4 April 1987 in the Belgian city of Knokke, Delors openly pleaded for the free movement of capital as a trait d'union between the internal market and a strengthening of the EMS. The crucial element in Delors' argument: both things had to move in parallel. However, the West German and Dutch ministers of Finance, the Christian Democrats Gerhard Stoltenberg and Onno Ruding balked. They strongly objected to this EC-logic (Bakker, 1996, p. 195). ${ }^{4}$ Eventually, this resulted in the so-called Basle-Nyborg Agreement, by which closer coordination of monetary policies among the ECmembers was arranged. To a certain extent, the material side of this cautious step-by-step institution building manifested itself in the form of a bilateral deal that was struck between the Banque de France and the Bundesbank in reaction to the Wall Street crash of 1987. Frankfurt came to the rescue of the franc and prevented an exit of the currency from the European Monetary System (EMS) by heavy intervention in the capital markets.

The subsequent step of institution building was already on the cards during the West-German presidency in the first half of 1988 - so well before the fall of the Berlin Wall. Basle-Nyborg and the European aftermath of the Wall Street crash built the background against which the French and Italian Finance ministers, Édouard Balladur and Giuliano Amato, wrote the historical letters, in which they called for a European Central Bank (ECB) to replace the EMS. Moreover, the changing circumstances induced the West-German foreign affairs minister, HansDietrich Genscher, to state publicly that he considered EMU and ECB part of a necessary and urgent next phase of European integration. Genscher got backing from West German business and multinational banks.

During the spring of 1989, the constituent parts of future EMU came together. On 17 April Delors presented a blue print for a future EMU based on the unanimous consent of Europe's Central Bank Presidents (the famous DelorsReport). And during the Franco-German summit of Evian in June, Mitterrand and Kohl prepared the successful concluding of the West-German EC-presidency later

\footnotetext{
${ }^{4}$ Their opposition forced the Belgian presidency to delegate technical compromising to trilateral negotiations of the Monetary Committee, the Committee of Central Bank Presidents and the EC.
} 
that month in Hanover. This was revolutionary and daring affair. The socialist Mitterrand granted Kohl French consent with the free movement of capital and the 'Europe of Banks' inherent in that, while anticipating a broader FrancoGerman EMU-deal in the not too distant future as a quid pro quo for this substantial gesture (Schwarz, 2012, 433-34; Connolly 1995: 70; Archives of the Dutch Foreign Ministry, The Hague [BZ], 996 EG, 1985-1989, 1624, ChabanDelmas to Van den Broek, 14 June 1989).

This changed the situation in EMU-matters. The 'political momentum' behind EMU became overwhelming (Jabko, 1999, p. 481). This became manifest during the ECOFIN council of 9 September 1989 in Antibes (in which the members of the Monetary Committee participated too). ${ }^{5}$ In this meeting, Delors, now endowed with the power connected to the follow up of his astonishingly popular report, again emphasized the parallelism between strengthening of the EMS and the free movement of capital. His German and Dutch opponents were weakened by the Mitterrand-Kohl deal of Evian, and Delors stepped up his game and proposed a far-reaching institutional reform following a road map of EMU first and EPU as a final stage (BZ, 996 EG, 1985-1989, 1624, Maas to DGES plus appendix, 5 October 1989).

In essence, this meant two things. First, it implied the reversal of the Krönungstheorie. Second, it triggered a politicization of EMU-building by the broadening of the circle of experts involved, far beyond the inner-world of monetary technocracy (i.e. breaching the monopoly of the Monetary Committee and the ECOFIN on EMU-negotiations). Together these developments set the scene of the well-known episode of historical Franco-German rapprochement orchestrated by Kohl and Mitterrand. This was the historical plot that threw into gear present day EMU and Euro. The institutional outcome of it was characterized by a highly problematic combination of a monetary focus on price stability (an independent ECB modelled on the Bundesbank), completely liberalized movement of capital, and far from optimal labour market integration (cf. Jones, 2002, pp. 103-120). Moreover, the outcome prevented the member-

\footnotetext{
${ }^{5}$ A sign that 'Basle Nyborg' worked in driving Europe's monetary experts together in a new and common arena of EMU building.
} 
states of building something like a fiscal and/or budget union as a countervailing power of financial-economic prudence within the EMU framework. And last but not least, this outcome laid the foundation for the largely politically inspired broad start of the final phase of EMU in 1999, including EU-members such as Italy and Spain, and subsequently Greece (2001).

It has been this largely unforeseen development of EMU that defines the problems to be tackled by the future 'deepening economic coordination' that Van Rompuy has announced. Yet, this historical evolution of EMU also sets the boundaries for additional arrangements within that framework.

\section{Economic prescriptions for a monetary union and its complications}

Given Van Rumpuy's plea for a voluntary 'deepening of economic cooperation', a major intellectual challenge in the design of an EMU between federalism and nationalism will be how to cope with policy coordination. In fact, also within a nation-state it is important to coordinate between the various economic policy fields in order to enhance welfare, given the political preferences.

Three major fields play a role in the economic debate on policy coordination: (i) monetary policy (ii) fiscal policy/(budgetary policy), (iii) labour market policy. Different exogenous developments or shocks to the economy may warrant a different mix of policy measures in these fields. Whereas finding the best policy mix to cope with these developments within a nation may already be complicated, it is obvious that solving the coordination problem between nations is even far more complex. A prerequisite for coordination within a union of nations is that it should lead to higher total welfare in the union compared to each individual country following its own policy in a way, which yields the highest welfare in the own country. In other words, policy coordination between member states in a union is only feasible if it brings extra welfare gains as compared to a regime of non-coordination. In policy practice of the EU this quest for welfare improvements may lead to long negotiations about the distribution of welfare gains from coordination, especially when horse-trading is needed because some countries are losing and others are winning. In the end, one way or the other, each country is bound to gain welfare from policy coordination in the EU. From that perspective the coordination game can be regarded as a way 
to come to a Pareto-improvement of the welfare distribution between the EU member states.

Role of European Central Bank

In a way the formation of a currency union and the establishment of the independent European Central Bank (ECB) brought focus to the coordination problem. Two major rationales from economic theory were instrumental in the institutional set up of monetary policy and the role of the ECB in the EMU.

The first rationale is the time consistency argument of Nobel prize-winners Kydland and Prescott (1977). This theory emphasizes the general negative effects on macroeconomic stability of the unpredictability that comes naturally from discretionary policy (see also Taylor 2012, 2013). Policy rules and the credible promise to keep to these rules reduce the negative effects of unpredictability that discretion brings about (see e.g. Blackburn and Chistensen, 1989). Obviously, in the political arena there always will be a preference for discretion and a tendency to constantly change the rules. In order to avoid this loss of credibility monetary policy is to be placed at distance from the policy debate. That is the reason why, especially in Europe on the road towards the establishment of the EMU, it has been stressed that the ECB should remain independent in the conduct of monetary policy. This quest for increased central bank independency has been crucial in the political discussions on how to institutionalize the ECB. Especially for Germany, an independent ECB, which mimics the role of the Bundesbank, was vital for the agreement to come to a currency union (Marsh, 2009, p. 167). Yet, at several occasions, national governments tried to challenge this central bank independency. Up to the 1980's the records for the various central banks with respect to their independence from government intervention were very mixed (Bade and Parkin, 1984). A way to protect the autonomy of the central bank against such challenge is to guarantee sufficiently long terms in office for the governor and the board of directors of the central bank (see Barro and Grilli, 1994).

The second argument from economic theory, which was instrumental in the institutional set-up of the ECB, is that an attempt of a central bank to actively react to output shocks by cyclical stabilisation policy, may affect the credibility of 
the commitment to anti-inflation policy. This argument is based on the reasoning of Barro and Gordon (1983) that monetary policy is only capable to influence output if the private sector does not anticipate such cyclical policy, i.e. when the monetary policy reaction to an output shock is unexpected. Rational economic agents, however, learn about such output targeting by central banks and will anticipate increasingly on future monetary policy reaction to output shocks. That will enhance inflation without altering the cyclical stance. Therefore limiting commitment of the central bank to inflation targets only, while ensuring independence from cyclical policies conducted by the government, enhances the credibility of the anti-inflation policy. Empirical evidence on the relationship between the independence of central banks and the record to keep inflation low, shows that the anti-inflationary reputation of a central bank is closely related to its degree of independence from the government (Barro and Grilli, 1994).

With respect to inflation targeting there is a clear difference between the Federal Reserve System (Fed) in the US and the ECB. The Fed has both inflation and the cyclical situation as targets in its political welfare function, whereas the ECB monetary policy targets remain limited to inflation. An empirical study by De Grauwe and Costa Storti (2005) tries to find alternative arguments for this difference between the Fed and the ECB. A reason may be that Fed can be more effective in activist monetary policy than ECB because there exist other types of labour market (wage) rigidities in Europe in comparison to the US; namely, nominal real wage rigidity in the US versus real wage rigidity in Europe. Nominal wage rigidities increase the output effects of monetary policy shocks so that in that case it provides a channel of monetary transmission from the monetary to the real side of the economy. Real wage rigidities reduce the effects of these shocks, so that in this case the monetary transmission channel does not work. However, De Grauwe and Costa Storti conclude from a meta analysis of a large number (83) of empirical studies of the effects of interest rates (and money stock) as policy instruments on output and price inflation that there is not much difference for the scope of an activist monetary policy between the US and Europe. So from that perspective it would also be possible for the ECB to have the cyclical situation as explicit policy target. Therefore, the major reason for the ECB focussing on inflation as the sole policy target seems the central bank independency and time consistency arguments discussed above. 
The coordination problem in theory and practice In present day EMU monetary policy is delegated to the ECB. Consequently, asymmetric - country specific - shocks no longer can be absorbed by national monetary policy of the individual member states, e.g. by exchange rate policy. It is fiscal policy and labour market policy, which is left at the discretion of the national governments to deal with these kinds of shocks. In theory the available instruments in fiscal policy and labour market policy suffice to enable welfare enhancing policy coordination in a monetary union. This is especially true when there is economic convergence in the members of the union so that the asymmetric shocks are relatively small as compared to the symmetric shocks monetary policy can deal with. There are differences of opinions on whether a monetary union will indeed contribute to such convergence (see Verhoef, 2003). The European Commission (1990) argues that shocks will become more symmetric because intra industry trade will increase in the EU. On the other hand there is the so-called 'Krugman view', claiming that asymmetric shocks will gain importance as the reduction of transaction costs in the EU will lead to more specialisation and fragmentation of production, exploiting comparative advantages.

There are two reasons why welfare enhancing policy coordination is much more difficult in practice than in theory. The first reason is that it is very difficult to distinguish between the various types of shocks - demand shocks versus supply shocks; country specific shocks versus region specific shocks versus industry specific shocks versus idiosyncratic, firm specific shocks. Another identification problem is whether shocks originate from the goods market, from the labour market or from the financial markets.

Following Bayoumi and Eichengreen (1992) a whole number of empirical time series analyses (see e.g. the 83 studies used by De Grauwe and Costa Storti, 2005) has been conducted to indentify various types of shocks and to measure the extent of (a)symmetry. An example is the research by Verhoef (2003), who uses bivariate SVAR models to calculate aggregate supply and demand shocks. He subsequently measures the (a)symmetry of by means of correlation and/or principal component analysis of these calculated shocks. This analysis shows 
that there is a division between core and periphery countries in the EMU where correlation coefficients are calculated vis-à-vis Germany as the centre of the core. Moreover it seems that the symmetry of the demand shocks has increased in the last two decades of the previous century, whereas the results on supply shocks are mixed. Yet there are some identification problems when measuring the (a)symmetry of shocks. Endogenous policy responses and spill over effects between EU countries can disturb measurement of shocks: in case of symmetric shocks but asymmetric propagation mechanisms, there will be a measurement bias towards asymmetry. However, from a practical policy point of view a much greater drawback is that such time series measurement can only provide evidence on the type of shocks and their order of magnitude in retrospect. In practice it should be known which types of shocks are hitting the economy of today. Such identification and measurements of shocks in real time is not altogether feasible.

The second reason why welfare enhancing policy coordination is extremely difficult in practice is that, even when the shocks could be perfectly identified and their sizes and correlations would be known, the theory of optimal coordination gives rise to a casuistry of policy rules far beyond which can be applied in political decision making. This is illustrated in a study by Beetsma et al. (2001). They discuss the question to what extent fiscal policy coordination in EMU is desirable. These authors very much simplify the policy coordination problem by using a two-country (two = many) model with one monetary authority (ECB) and fiscal policy conducted by the fiscal authorities in both countries. This model contains three policymakers; home and foreign fiscal authorities and the ECB, with three societal welfare functions - with the ECB targeting inflation, and the two fiscal authorities targeting both inflation and output. It is supposed that the two governments have the same preferences with respect to these two targets. The model of Beetsma et al. distinguishes three external effects of policy responses, which may make policy coordination desirable and welfare enhancing. There is a direct aggregate demand effect through international trade linkages, an indirect interest rate effect through the reaction of the ECB to the decisions of the fiscal authorities and a real exchange rate effect (note: nominal exchange rates are fixed). Two forms of coordination are distinguished: ex ante commitment to coordination (by means of pacts, 
treaties, fixed policy rules) versus ex post coordination whereas the welfare effects of various policy responses to symmetric and asymmetric supply and demand shocks are also calculated in case no coordination takes place. In this very simple and stylized model the optimal policy coordination already appears to be very complicated and to depend much on the types and sizes of shocks, and on the assumptions with respect to trade linkages and policy preferences and institutions. The model shows that there may even be counterproductive coordination in case of large symmetric shocks. Moreover, possible negative spill-over of externalities due to terms-of-trade effects would alter conclusions and the dynamic effects of fiscal policy through inter-temporal budget constraint are not taken into account. Inclusion of the labour market in the model would further complicate the casuistry. Such extension of the model seems relevant in respect to the policy discussions in the EMU where especially the labour market is to absorb asymmetric shocks now that fiscal policy leaves little room de manoeuvre

All in all, the main lesson from this reading of the economic literature on policy coordination is that, in principle, welfare enhancing policy coordination is possible, but in practice the required knowledge on the various types of shocks (demand versus supply, symmetric versus asymmetric) will never be available.

\section{Fiscal discipline, contagion and the key role of financial markets}

Section 4 shows that in practice achieving Europe-wide policy coordination is very difficult. The recent financial crisis in the EMU, with large deficits and growing government debts has made adequate policy coordination even more problematic now that the scope for absorbing country specific shocks using fiscal policy has become limited.

The essence of the problem

A major reason for the present EU debt problem is that the fiscal discipline of the Euro countries has fallen sharply in 1999, after the exam based on the criteria of the Maastricht Treaty was passed and the countries joined the Euro. It is obvious why. In the years preceding the exam, the candidate Euro countries took huge efforts, sometimes even with a lot of creative accounting, to pass the exam (Annett, 2005). During that period the countries had a strong incentive to 
become member of EMU, and markets provided them with a strong financial incentives. The exam seemed a trigger mechanism in the policy coordination game. Moreover, the overarching goal of Euro-membership was also frequently used as an excuse for the own population to justify a strict fiscal policy. These discipline-enhancing dynamics as laid down in the Stability and Growth Pact (SGP) weakened after the introduction of the Euro. This standstill under the SGP reflected adjustment fatigue (Annett, 2005). Moreover, as mentioned above, the fines that the SGP was to impose to violators of the criteria were credible as long as Germany unambiguously backed this interpretation of the SGP in the ECOFIN. However, when first France and later even Germany violated the rules, the threat of being fined lost credibility, so that also the rules based policy prescriptions of the SGP with respect to maximum sizes of government deficits and debts lost credibility. In most EMU member states fiscal policy became again discretionary rather than rules based.

Gardner (2001) describes how the gains from being member of a currency union can be explained by the theory of clubs (see also Ahrens et al, 2005). In this view the EMU can be perceived as a club that provides several non-rival but excludable goods and services to its members. Membership of the club is profitable when the gains from these provisions outweigh the costs of the membership fee and the costs of complying with the rules of the club. Yet, unlike most clubs, the EMU has no forced exit option for members who misbehave and violate the rules. In that respect the EMU looks like Hotel California from the famous song of The Eagles: 'We are programmed to receive. You can check-out any time you like, but you can never leave.'

The fact that some EU countries had, so to say, a different attitude towards budgetary discipline in their policies than others made the coordination problem even more complicated. Countries with looser morals, such as Greece, Portugal, Italy, Spain, and from another perspective, I reland, have benefited from the cheap financing of budget deficits made available by the financial markets on the basis of the soundness of Euro-partner-countries such as Germany, Finland, Austria and the Netherlands. The consequence is that the countries with strict fiscal policies are reluctant to show solidarity with countries with less fiscal discipline. 
Contagion and the role of financial markets

Another major reason for the debt crisis in the EMU and the resulting complications of coordination is that the production chains and the global financial markets become more and more intertwined and entangled. It enhances the risk of contagion and makes it more difficult to apprehend which externalities should be accounted for in policy coordination at an EMU wide scale. Forbes (2012) defines contagion as the situation that a large negative shock in one financial institution, or in one country, rapidly spreads to other financial institutions or other countries. That is why contagion is associated with externalities and why avoiding contagion has become a major goal of policy coordination. An important nuance in this description of contagion regards the size of the negative shock. The idea is that contagion occurs only at a 'big' shock, so when a certain threshold is passed. This distinction between normal times and times of crisis, or between an ordinary negative shock and an exceptionally large negative shock, has important implications for policy (Forbes, 2012, p. 5 ). Thus, - when it comes to countries - there is a difference to be made between the dependencies between countries that always existed, the normal 'interdependencies ' and the dependencies that exist only after the large negative shock has occurred. If in the first case a negative shock in one country propagates to other countries, for example through existing trade channels, it is not advisable to sterilize the shock by providing liquidity or by other forms of financial support. This policy can just delay the necessary structural adjustments. When, however, the contagion occurs through channels, which arose only shortly after the shock, a policy of providing liquidity or another form of financial support may stabilize the economy. Then an unnecessary and painful adjustment process is avoided.

Forbes identifies four channels through which contagion can occur. A first channel is trade. A substantial fall in demand in one country can reduce income and the corresponding demand for imports, thereby affecting exports from other countries through bilateral trade. This is the channel of transmission, which is explicitly considered in Beetsma et al (2001). Most empirical papers find that trade channels are significant and play an important role in transmitting crises. They also find that trade does not explain all of the contagion observed during recent crises and that other transmission channels are also important. 
Consequently, a second important channel, which is most relevant in the banking crisis and the subsequent debt crisis, relates to banks and lending institutions. A shock to one country can cause banks to reduce the supply of credit in other countries, reducing liquidity and raising the cost of credit. Moreover negative shocks to banks are magnified in the presence of leverage, causing an even greater reduction in loans and unwinding of positions. Empirical evidence shows a striking increase in international bank exposure in the Euro zone and advanced economies since the mid/late 1990s. There is also a steady increase in bank leverage in the Euro countries over the same period. These trends of increased international bank exposure and banking leverage in Euro zone countries can be regarded as important factor causing enlarged contagion over time in the Euro zone.

In the third place Forbes regards the behaviour of portfolio investors as another financial channel for contagion. There are various mechanisms by which investors can transmit shocks across countries. In the simplest versions, an idiosyncratic shock to one country reduces the value of investors' portfolios, forcing them to sell assets in other countries to meet margin calls or cash requirements or to rebalance portfolios. Financial data show that, starting in the mid-1990's, and up to 2007 international investment positions and portfolio inflows increased sharply in the Euro zone. This relatively large increase in international portfolio investment exposure in the Euro zone as compared to other areas is not surprising as one of the key goals of the euro was to increase financial integration across members. This again seems to have been an important channel for contagion in the Euro zone.

A fourth channel of contagion distinguished by Forbes is a reassessment of fundamentals or a "wake-up call". It describes the situation that additional information or a reappraisal of one country's fundamentals leads to a reassessment of the risks in other countries. A major example of such a wake-up call is the tampering with statistics in Greece and the consequent realization by the financial markets that bonds in euro's may not be as safe an investment as originally thought. 
In a regression analysis Forbes (2012) shows that each of these four distinct channels of contagion has contributed to the emergence of euro crisis. It seems that the role of leverage is most prominent.

Goodhart (2011) adds as a source of contagion that the Euro zone countries with balance of payments surpluses, such as the Netherlands and Germany, have invested in countries with balance of payments deficits, while the usual equilibrium mechanisms were not at work and did not cause a reduction of the surpluses and deficits.

The above discussion on contagion explains the crucial role of the financial markets in the banking and euro crises. Because of the increased entanglement of international financial markets and the resulting thread of contagion, the nobailout option lost credibility, both at the level of individual "systemic" (or "too big to fail") banks and at the level of the Euro zone as regard to the no-bailout option of the SGP. In the case of banks it resulted in too risky behaviour as the gains from taking risks were privatised whereas the losses were averted to the public sector. In the case of the EMU it resulted in lax fiscal policies of those member countries that became addicted to low interest rates for government borrowing, while European banks were happy and eager to make good profits by using cheap money to buy state bonds from the European governments with large deficits. In both cases it was the threat of contagion which forced the bailouts. In both cases it were finally the taxpayers who had to pay for the bailouts.

\section{Avoiding the Brinkmanship strategy}

In case of the Euro crisis the imported thread of contagion forced the countries with good fiscal discipline to accept high-risk guarantees to save the Euro. The alternative seemed an extremely costly chaos at financial markets. Obviously the financial markets and the governments of EMU members with lax fiscal discipline realized that the core EMU members and the ECB were faced with this dilemma. In a way they took the core countries hostage with the costs of the bailout as ransom. In game theory this threat is called a Brinkmanship strategy: it is the practice of pushing dangerous events to the verge of-or to the brink of disaster in order to achieve the most advantageous outcome. A major question is how the EMU can be re-institutionalised in such way that the destabilizing role 
of the financial markets through the threat of contagion is converted to a stabilizing role where financial markets have an incentive to avoid contagion and to be helpful in promoting fiscal discipline.

A way to involve the financial markets in assessing fiscal discipline and hence enhance the scope for coordination in the EMU is discussed by Fahrholz and Wójcik (2012) in the context of the Brinkmanship strategy. The main argument in this theoretical game analysis is that the negative externalities through the threat of contagion give rise to a threat game between countries with lax fiscal discipline (periphery, PER) and countries with fiscal discipline and sustainable debts: the core countries (CEN). In line with the discussion on contagion above the negative externality arises from potential default of countries from the periphery. The analysis assumes - in line with our observations - that the EMU will not, due to political preferences, converge to a federal state with one fiscal policy regime. In the game theoretical framework of Fahrholz and Wójcik the commitment to fiscal discipline should be credible with fiscal discipline enforced by voters and financial markets. In such a situation a default on government bonds can be both disadvantageous for the 'core' and the 'periphery' of the monetary union. As such this game theoretical analysis provides another and strong argument for fiscal policy coordination in a monetary union.

An important aspect of the analysis of Fahrholz and Wójcik is that they consider exit rules, which may change the outcome of the game and the negotiation on the outcome. These exit rules are, according to their analysis, necessary to shift the relationship between CEN and PER in the Euro zone in such a way that brinkmanship behaviour within the Euro zone is mitigated and Euro zone stability is safeguarded. Exit rules may thereby contribute to better involve voters and financial markets in enhancing fiscal discipline and hence in providing a better scope for policy coordination. If exiting in the Euro zone were openly allowed, the markets would immediately price non-zero probabilities into their risk assessment and hence better differentiate the country risk among sovereign bonds of euro zone members. So exit rules would decrease (and not increase) the probability of an exit, or break-up of the Euro zone. Therefore a (mandatory) exit rule can be regarded as a "nuclear option". In theory, there are two additional channels through which exit rules could enhance stability in the Euro 
zone: (i) it would increase political bargaining power of euro zone members with respect to profligate countries; (ii) it would provide the added benefit of decreasing market uncertainty which would support the political and economic adjustment processes.

\section{Alternatives for a mandatory exit}

From a political perspective a mandatory exit is not on the cards, given the political prestige already invested in keeping the Euro zone together, in particular by Angela Merkel. This is especially true after the President of the European Central Bank Draghi, in a speech on July $26^{\text {th }} 2012$ in London, has pledged to do "whatever it takes" to protect the Euro zone from collapse including fighting unreasonably high government borrowing costs. This commitment has proven to be credible and convincing so that financial markets indeed ceased to be destabilizing and investors felt safe enough to hold on to the bonds issued by European governments. However, it did not bring the structural solution of urging governments to fiscal discipline by a reduction of the treat of contagion through incentives for the financial markets to disable a brinkmanship strategy.

Therefore, a promising alternative to a mandatory exit option for a credible trigger in the fiscal policy coordination game seems the proposal of the Brussels think tank Bruegel (Depla and Von Weizsacker, 2010) for the issuance of blue and red bonds for the debt financing of Euro countries. The idea is to allow EMU members to finance up to $60 \%$ of GDP by means of blue Eurobonds, which will be issued collectively by all Euro countries on the proposal of an independent stability board. Deficits which raise the debt above 60\% GDP should then be financed by the countries themselves with junior red bonds. The interest rate on the blue bonds will be low because the market will regard these bonds as lowrisk. It is conceivable that the interest rate on blue bonds will be about equal to the interest rate on bonds of countries with the largest fiscal discipline (eg. Germany). By contrast, interest rates on red bonds will vary considerably and will for the countries with lax fiscal discipline be high relative to the interest on blue bonds. This constitutes an incentive for countries with a debt over $60 \%$ of GDP to be strict on the deficit and to reduce the debt gradually. In fact this proposal for blue and red Eurobonds seem to fit nicely in balancing the federalist 
and intergovernmental institutional set up of the EMU. The blue bonds represent the federalist view and the red bonds the intergovernmental view.

Yet this and similar proposals to issue Eurobonds have drawbacks and loose ends. A drawback is that there is hardly an incentive for countries to reduce their debt below $60 \%$ ( or $50 \%$ ) of GDP. A further reduction may, however, be warranted in order to keep public finance sustainable in the long run in the coming era of ageing and dejuvenation of the population. For that reason the recommendation of the SGP is a budget "close to balance or in surplus". This drawback could be alleviated by fixing a timetable for the percentage to GDP of debt, which could be financed by means of blue Eurobonds. Here the allowed percentage should be gradually reduced. Another drawback is that the countries with strict fiscal discipline will vote against the issuance of Eurobonds when they expect that the interest rate to be paid on Eurobonds will be higher than the interest on government bonds issued by these countries themselves. That is why the German chancellor, Angela Merkel, has opposed plans to issue Eurobonds. The problem could be circumvented, by making the financing of the national debt via Eurobonds a voluntary matter. In the blue and red bond proposal this would allow Germany to finance its debt with red bonds, in which case probably would require lower interest rates than when using the blue Eurobonds. However, this means a strong limitation of the proposal because it probably means that the countries with fiscal discipline will continue to finance their entire debt with their own government loans.

Commitment to fiscal discipline can be obtained, as rising interest rates on the red bonds, or on the own government loans, constitute an early warning signal that greater fiscal discipline is really needed.

Bail-in and the European banking union Here the solution taken in the crisis in Cyprus with a bail-in - in fact it is a partial bailout where owners of stocks, bonds and other assets pay part of the costs of the rescue - can act as a blueprint. This new institutional framework would change the rules of the coordination game between the fiscal authorities and the financial markets in such a way that now the financial markets have an interest in rescuing the Euro instead of attacking it. That is because attacking 
the Euro through asking higher rates of return on red bonds will enhance the probability of a bail-in, which is not in the interest of owners of these bonds.

The rules for a bail-in play a prominent role in the design of the Single Resolution Mechanism (SRM) as part of Europe's banking union. On December $18^{\text {th }}, 2013$, the EU Council reached a compromise agreement on a draft regulation of this SRM, where member states were committed to negotiate, by 1 March 2014, an intergovernmental agreement on the functioning of a Single Resolution Fund (SRF). The additional costs of a bail-in (or partial bailout) in case of failure of a systemic bank supervised by the ECB in the banking union (SSM: Single Supervisory Mechanism) are paid out of this fund. The rules proposed for this SRM and SRF are a neat illustration of how the EMU proceeds on its way between federalism and nationalism. The SRF is financed by bank levies raised at national banks. I nitially it consists of national compartments so that a bank failure is primarily paid by the national banks of the home country of the failing bank. Gradually, in a period of ten years, the mutualisation of the compartments would increase so that in the end the fund obtains a supranational character. With respect to the resolution of banks the proposal opts for a centralised decision-making built around a strong Single Resolution Board (SRB). The decision-making by this Board, which owes the fund, involves the Commission, the Council, the ECB and the national resolution authorities. All in all this institutional set-up of a part of the European banking union shows how complex the road to further integration and coordination in the EMU is.

The agreement about the rules of a bail-in, where the costs of resolution of banks are no longer exclusively borne by the tax-payers, is an important step forwards to reduce the threat of contagion. It diminishes the moral hazard of too risky behaviour of systemic banks in case they reckon on a bailout by way of systemic risk insurance. In that sense the bail-in may act as a trigger mechanism in the game banks play with supervisors who want to avoid contagion. The bail-in provides the supervisory authorities with a much stronger instrument to reduce the incentives of banks for excessive risk taking than the prospects of a bailout which may also protect banks against contagion, as it removes a source of exogenous risk for banks so that it may increase bank incentives to monitor loans (Dell'Ariccia and Ratnovski, 2013). Yet, some more 
work has to be done in order to come to feasible and practical rules for resolution of banks that operate internationally, e.g. by letting the banks write "living wills" which set out how banks could be stabilised or shut down in case of a crisis (see e.g. Avgouleas et al. 2013).

\section{Defining the middle way: EMU without EPU}

In principle there are three different ways to proceed from the present status quo in the process of European political and economic integration. The first way is to make the present monetary union a full-fledged political union. However, this road towards a federalist Europe does not seem viable, given the political and cultural preferences and differences in the various Euro zone member states. Moreover in his London speech of 28th February 2013 the President of the European Council, Van Rompuy has, in a way, blocked a road to further federalization. The second way is to return to country currencies and abolish the common monetary policy. This nationalist solution neither seems viable, as it will be very costly and wipe out a lot of benefits that the common policy has brought about (see e.g. Beetsma and Giuliodori, 2010). This leaves a third road to be explored, namely the middle way of compromise between federalism and nationalism. This paper discusses the political history of this road and tries to answer the question how the EU can be further institutionalised, so as to conduct welfare enhancing economic policy coordination in the best possible manner.

The essence of the welfare enhancing nature of policy coordination is that it reckons with the external effects that national policies - and for that manner the common monetary policy of the ECB - bring about in reaction to various types of exogenous shocks that hit the economy. In a currency union monetary policy deals with symmetric shocks in a way that leaves it to fiscal policy and the labour market to react to asymmetric shocks. In present day EMU this implies that in a number of member states ample reform still is needed to make labour markets more flexible to deal with these asymmetric shocks. However, this should be done while safeguarding a certain extent of social security in line with national preferences.

Yet the most serious problems remain in the domain of fiscal policy, now that the debt crisis has reduced the scope for fiscal policy in most EMU members. 
Nevertheless, policy coordination, and fiscal policy coordination in particular, has become essential as goods and service markets as well as financial markets increasingly get entangled. Within the EMU this amplifies the externalities that policy coordination has to deal with. It should be noted that such further integration of markets was a goal of EMU in the first place and should not be hindered. However, the dilemma remains that the entanglement of the financial markets resulted in a threat of contagion, which was used by EMU members with loose fiscal discipline to obtain a bailout and defy the no bailout clause in the SGP. The top question in further institutionalizing EMU is how to deal with this dilemma.

There are two options. The first option is to try and reduce the threat of contagion. A banking union with EMU wide supervision of banks can be instrumental where banks are forced to take less risk, to have lower leverages and be recapitalized if necessary. This micro-prudential supervision at the EMU level should, however, be complemented with adequate macroprudential supervision in order to reduce contagion and prevent systemic banks to be "too big to fail" (or rather "too entangled to fail": see Den Butter, 2011; Gai et al., 2011, Houben and Kakes, 2013). Government efforts to rescue these "too big to fail" banks have in part been responsible for the debt crisis.

The second option is to try and reduce the possibility to make use of the threat of contagion by means of a brinkmanship strategy. This paper gives some suggestions for this second option, such as the use of a bail-in and distinguishing between blue and red bonds to finance government debt. The upshot is that policy rules are to be designed in such a way that it is in the interest of the financial markets to bring about fiscal discipline, so that fiscal policy can again be fully used in dealing with asymmetric shocks. Yet even in that case there is much casuistry in the rules for good policy coordination from the economic perspective, so that also the political process of policy making should be well designed in this future EMU between federalism and nationalism. The compromise proposals of December 2013 for a Single Resolution Mechanism as a key element of Europe's banking union provide a neat example of the complexity of this process of political design. 


\section{Literature}

Ahrens, J., H.W. Hoen and R. Ohr, 2005, Deepening integration in an enlarged EU: a club-theoretical perspective, Paper presented at the EPSC conference 2005.

Anderson, Perry, 2009, The New Old World (Londen, New York: Verso).

Annett, A., 2006, Enforcement and the Stability and Growth Pact: how Fiscal Policy did and did not change under Europe's Fiscal Framework, I MF Working Paper WP/06/116.

Archives of the Dutch Foreign Ministry, The Hague [BZ], 996 EG, 1985-1989, 1624.

Attali, J., 1993 and 1995, Verbatim I and III (Paris: Fayard/Le livre de poche).

Avgouleas, E., C. Goodhart and D. Schoenmaker, 2013, Bank resolution plan as a catalyst for global financial reform, J ournal of Financial Stability, 8, to appear.

Bade, R. and M. Parkin, 1984, Central Bank Laws and Monetary Policy, Department of Economics, University of Western Ontario, Canada.

Bakker, A., 1996, The Liberalization of Capital movements in Europe. The Monetary Committee and Financial Integration 1958-1994 (Dordrecht: Kluwer).

Baldwin, R. and Ch. Wyplosz, 2012, The Economics of European Integration, 4th Edition, McGraw-Hill, London/Boston.

Barro, R.J . and D.B. Gordon, 1983, Rules, discretion and reputation in a model of monetary policy. Journal of Monetary Economics, 12, pp. 101-121.

Barro, R.J. and V. Grilli, 1994, European Macroeconomics, Macmillan Press Ltd, Houndmills, Basingstoke, (see ch. 22).

Bayoumi, T. and B. Eichengreen, 1992, Shocking aspects of European monetary integration, NBER Working Paper, no. 3949.

Beetsma, R., X. Debrun and F. Klaassen, 2001, Is fiscal policy coordination in the EU desirable? , Swedish Economic Policy Review, 8, pp.57-98. 
Beetsma, R.M.W.J . and M. Giuliodori, 2010, The macroeconomic costs and benefits of the EMU and other monetary unions. An overview of recent research, Journal of Economic Literature, 48, pp. 603-641.

Blackburn, K. and M. Christensen, 1989, Monetary policy and policy credibility: theories and evidence, Journal of Economic Literature, 27, pp. 1-45.

Bundesminsiterium der Finanzen, 1995, Stablitätspakt für Europa, November 1995.

Butter, F.A.G. den, 2011, The macroeconomics of the credit crisis: in search of externalities for macro prudential supervision, in E.F.M. Wubben (ed.), Institutions and Regulation for Economic Growth? Public Interest Versus Private Incentives (Edward Elgar Publishing), pp. 187-209.

Cini, M. (ed.), 2007, European Union Politics (Oxford: Oxford University Press).

Connolly, B., 1995, The Rotten Heart of Europe. The Dirty war for Europe's Money (Londen \& Boston: Faber\&Faber).

Dell'Ariccia, G. and L. Ratnovski, 2013, Bailouts and systemic insurance, IMF Working Paper WP 13/233, November 2013.

Delors, J., 2004, Erinnerungen eines Europäers (Berlin: Parthas Verlag)

Deutsche Bundesbank, 1992, 'The Maastricht Decisions on EMU', Monatsberichte der Deutsche Bundesbank, februari 1992

Delpla, J. and J. Von Weizsacker, 2010, The blue bond proposal, Bruegelpolicybrief, 2010/3, May 2010.

European Commission, 1990, (Commission of the European Communities; Directorate-General for Economic and Financial Affairs), One market, one money: an evaluation of the potential benefits and cost of forming an economic and monetary union.

Fahrholz, Ch. and C. Wójcik, 2012, The Eurozone needs exit rules, CESifo Working Paper No. 3845.

Forbes, K., 2012, The "big C", I dentifying contagion, NBER Working Paper no. 18465. 
Gai, P., A. Haldaney \& S. Kapadiaz, 2011, Complexity, concentration and contagion, Journal of Monetary Economics, 58, pp. 453-470.

Gardner, R., 2001, The enlargement, Ch4 in M. Artis and F. Nixson (eds.) The economics of the European Union; Policy and analysis; third edition, pp. 81-96.

Goodhart, C., 2011, Global macroeconomic and financial supervision: where next?, NBER Working Paper 17682, December 2011.

Grauwe, P. de, and C. Costa Storti, 2005, Is Monetary Policy in the Eurozone less Effective than in the US?, CESifo Working Paper no. 1606.

Habermas, J., and P. Bofinger, 2012, 'Only deeper European unification can save the eurozone', The Guardian, 9 August 2012.

Heisbourg, F., 2013, La fin du rêve européen (Stock)

Hewitt, G., 2013, The lost continent (London: Hodder)

Jabko, N., 1999, 'In the name of the market: how the Commission paved the way for monetary union', Journal of European Public Policy, 6, 3, pp. 475-495.

Jones, E., 2002, The Politics of EMU. Integration and Idiosyncrasy (Lanham, etc.: Rowman \& Littlefield).

Jones, E., 2010, The Economic Mythology of European Integration, Journal of Common Market Studies, 48, 1, pp. 89-109.

Kydland, F. and E. Prescott, 1977, Rules rather than discretion: the inconsistency of optimal plans, Journal of Political Economy, 85, pp. 473-491.

Houben, A. and J. Kakes, 2013, Financial imbalances and macroprudential policy in a currency union, DNB Occasional Studies, 11, 5.

Ludlow, P., 1982, The Making of the EMS (Londen: Butterworth).

Marsh, D., 2009, The Euro. The Politics of the New Global Currency (New Haven \& Londen: Yale University Press).

Mourlon-Druol, E., 2012, A Europe Made of Money. The Emergence of the EMS (Ithaca, New York: Cornell University Press). 
Mundell, R.A., 1961, A theory of Optimum Currency Areas, American Economic Review, 51, 4.

Oort, C.J., 1974, The exchange rate regime of the future, The Per Jacobsson Foundation, Steps to international monetary order, 11 oktober 1974, Tokio.

Padoa-Schioppa, T., 2000, The Road to Monetary Union in Europe (Oxford: Oxford University Press).

President of the European Council (Van Rompuy), 2012, Towards a Genuine Economic and Monetary Union, Brussels, 26 J une 2012.

President of the European Council (Van Rompuy), 2013, Annual Conference of Policy Network, 'Britain in Europe: channelling change together', London, 28 February 2013.

Sadeh, T., and Amy Verdun, 2009, Explaining Europe's Monetary Union: A Survey of the Literature, International Studies Review, 11, pp. 277-301.

Schwarz, Hans-Peter, 2012, Helmut Kohl. Eine politische Biographie (München: DVA).

Segers, Mathieu en Femke van Esch, 2007, Behind the veil of budgetary discipline. The political logic of budgetary rules in EMU and the SGP' J ournal of Common Market Studies, 45, 5, pp. 1089-1109.

The Spinelli Group / Bertelsmann Stiftung, 2013, A Fundamental Law of the European Union (Verlag Bertelsmann Stiftung).

Taylor, J.B., 2012, Monetary policy rules work and discretion doesn't: a tale of two eras, Journal of Money Credit and Banking, 44, 6, September 2012, pp. 1017- 1032.

Taylor, J.B., 2013, 'The Effectiveness of Central Bank Independence Versus Policy Rules', paper prepared for the session "Central Bank Independence: Reality or Myth?", American Economic Association Annual Meeting, San Diego, California, January 2013. 
Van Riel, B. and A. Metten, 2000, De keuzes van Maastricht (Assen: Van Gorcum).

Verhoef, B.A., 2003, On the (a)symmetry of shocks in EMU, DNB Staff Reports no. 106, Amsterdam: DNB. 